\title{
Ecotoxicants Content of Sanguisorba officinalis L., Growing on Mining Disturbed Lands of Kemerovo Region
}

\author{
Natalya Egorova ${ }^{1}$, Irina Egorova ${ }^{l,}{ }^{*}$, Elena Maltseva ${ }^{2}$, and Andrei Sukhikh ${ }^{2}$ \\ ${ }^{1}$ The Federal Research Center of Coal and Coal Chemistry of SB RAS (Institute of Human Ecology \\ of the SB RAS), 10, Leningradskiy avenue, Kemerovo, 650065, Russia \\ ${ }^{2}$ Kemerovo State Medical Universit, 22a, Voroshilov street, Kemerovo, 650056, Russia
}

\begin{abstract}
Ecotoxicant content - heavy metals and radionuclides in embryonic soils and herbal medicinal products of Sanguisorba officinalis L. of the rose family (Rosaceae) in the circumstance of technogenically disturbed lands was analyzed, in example of the rock waste disposal area of the Kedrovsky coal pit in Kemerovo region. It was experimentally proved that the embryonic soils of the coal dump is characterized by large elemental variation. Analysis revealed that the raw materials of Sanguisorba officinalis L. more accumulates such metals as $\mathrm{Fe}$ $(61,95 \mathrm{mg} / \mathrm{kg}), \mathrm{Mn}(33,46 \mathrm{mg} / \mathrm{kg}), \mathrm{Zn}(17,53 \mathrm{mg} / \mathrm{kg})$ and $\mathrm{Cu}(12,35$ $\mathrm{mg} / \mathrm{kg}$ ), which are related to biophilic metals. Technogenical group of elements $-\mathrm{Pb}, \mathrm{Cd}, \mathrm{Cr}, \mathrm{Ni}, \mathrm{Co}$, are within $0,04 \ldots 1,52 \mathrm{mg} / \mathrm{kg}$. It was also experimentally proved that the main share in overall radioactivity of embryonic soils and rhizome and roots of greaterburnet falls to natural radionuclides, especially K-40. The share of Cs-137 and Sr-90 are about $7 \%$ in embryonic soils and 85 in rhizome and roots of burnet. Ecological hygienic assessment of Sanguisorba officinalis L. herbal medicinal products has shown the MPC no-exceedance of heavy metals and radionuclides, provided for the plant based BAA.
\end{abstract}

\section{Introduction}

A large number of medicinal plants that allowed for use in practical medicine are growing on the rock waste disposal areas of Kuzbass coal pits: Crataegus sanguine Pall., Pinus sylvestris L., Taraxacum officinale Web., Tussilago farfara L., Hippophaë rhamnoides L., Melilotus officinalis (L.) Pall., Urtica dioica L., Artemisia absinthium L., Chelidonium majus L. , Fragaria vesca L. , Tilia cordata Mill., Sorbus sibirica Hedl. et al. Among representative of rose family occurs Sanguisorba officinalis L. on coal waste dump [1].

Sanguisorba officinalis L. - is a perennial herbaceous plant with shortened vegetative and elongated generative shoots.

It is widely distributed in Kemerovo region, mainly in the forest and forest-steppe zones, in the belt of low-mountain taiga. It grows on dry forest, solonetsous meadows in sparse coniferous, mixed and birch forests, along river banks and prefer chernozem, forest podzolized, less frequently solonetsous soils. 
The greater burnet can be found in meadows, in inter-drainage depressions, mainly on loams on the territory of the rock waste disposal area of the Kedrovsky coal pit [2]. Large thickets do not form. However, the local people producesits raw materials. Shallow occurrence of underground organs facilitates the collection of this plant material.

Herbal medicinal products of Sanguisorba officinalis L. (rhizome and roots) and preparations based on it are widely used in scientific and ethnoscience both in Russia and abroad.

Rhizome and roots of Sanguisorba officinalis L. contain tannins, ellatanins, proanthocyanidins, catechins, flavonoids, phenolcarboxylic acids, triterpene glycosides, oleanolic and ursolic acid derivatives, polysaccharides, saponins, sanguvisorbin, lossans, sterols, colorants, essential oil, etc. [3].

Preparations made of Sanguisorba officinalis L. have a wide range of pharmacological action. They are used as astringent for gastrointestinal diseases (enterocolitis, diarrhea of various etiologies), as hemostatic for bleeding, for gargling, for the treatment of stomatitis and gingivitis, in cosmetology, etc. [3, 4].

The greater burnet used for inflammation of the stomach, intestines, poisoning, dyspepsia, respiratory diseases, bronchitis, female diseases: inflammation of the uterus, vagina, after abortion, with fibroids of the uterus, cancer, etc. in ethnoscience.

The rich chemical composition makes Sanguisorba officinalis L. a promising species for the development of new drugs [4,5].In addition, the raw materials of greater burnet are used in the production of combined, enriched food products [6].

However, coal mining waste could be a source of increased content of both radionuclides and heavy metals [7, 8]. Radionuclides and heavy metals are the most dangerous sources of environmental pollution.

The flow of toxicants into the human body occurs most often according to the scheme: soil - plant - a person. Elements which coming from the soil to the plant, passing through the food chains have a toxic effect on the plant and the human. They can enter into the biological cycle and accumulate in the human organism [9]. The presence of toxicants in quantities 2-3 times higher than background levels is undesirable in foods products, and in excess of the maximum permissible concentration (MPC) - is unacceptable [10].

These toxicants can enterin the human body with drugs (tinctures, decoctions, etc.), the raw material for the production of which are medicinal plants [9].

Therefore, studies in hygienic safety determination of medicinal plants growing in technologically altered areas for the evaluation of possibility of using in medicineare needs.

The goal of this work is to assess the pollution of herbal medicinal product (rhizome and roots) of Sanguisorba officinalis L. and adjacent embryonic soils with ecotoxicants (heavy metals and radionuclides) in the circumstances of the rock waste disposal area of the Kedrovsky coal pit.

\section{Materials and Methods}

The research was carried out at the Yuzhny rock waste disposal area of the Kedrovsky coal pit in the Kuznetsk region of Russia. The total square of the Yuzhny rock waste disposal area is 599.3 hectares. The relief is flat-inclined. Rocks, which the waste disposal areas consist of, are mainly represented by sandstone $(60 \%)$ including a large share of siltstone $(20 \%)$, clay stone $(15 \%)$, clay loam and clay $(5 \%)$. The predominant fraction is the large aggregates (from 3 to $10 \mathrm{~mm}$ and more), the concentration of fine biologically active microelements, as $\mathrm{Cu}$ and $\mathrm{Zn}$ - below particles is reduced.

Embryonic soil is represented mainly by heavy, medium concentration clay loam $(3.5 \%$ of humus), with its typically alkaline reaction of the soil solution ( $\mathrm{pH}$ of the water extract is 
equal to 7.1-7.7), low concentration of phosphorus and nitrogen (1.7-7.0), and a little below the normal level of exchange potassium $(125 \mathrm{mg} / \mathrm{kg})$. [11].

The rhizome and roots of Sanguisorba officinalis L. and adjacent embryonic soils collected over the period of 2012-2013 are the objects of the research.

Raw material was procured during the fruiting period, in dry sunny weather, according to the standard rules. The raw materials collected had no visible signs of damage. An average sample was prepared by quartering in accordance with Federal Standard 24.027.080. Embryonic soils were taken from the root layer $($ A $0-15 \mathrm{~cm})$.

Laboratory study of the embryonic soil and vegetation samples was carried out at the premises of the certified test center of the agrochemical service "Kemerovsky".

Elemental analysis of embryonic soils samples and plant raw material was performed using the atomic absorption method in air-acetylene flame in spectrophotometer AAS - 30 from Karl Ceis Jena (Germany). For extracting heavy metals from soil, ammonium acetate buffer was used with $\mathrm{pH} 4.8$ by Krupsky-Alexandrova method. Samples of plant raw materials were prepared by dry ashing followed by extraction with dilute nitric acid.

Radioactivity of the studied samples was detected using the Progress spectrometric detector for measuring the activity of alpha-, beta-, and gamma-emitting nuclides by «The Methodology of Measurement of the Activity of Radionuclides in the Computation Samples Using the Progress Software, approved by V.P. Yaryna, the Head of the Center of Metrology of Ionizing Radiation of the SSMC "VNIIFTRI" of "Gosstandard of Russia" on 07.05.1996."

Analyses were performed in three replications; results were statistically processed using Statistica 6.0 software.

\section{Results and Discussion}

Research results show that samples of Sanguisorba officinalis L. adjacent dump embryonic soils are characterized by considerable fluctuations of elemental composition (Table. 1).

The analysis of the obtain results shown that the investigated embryonic soils samples contain more $\mathrm{Mn}$ and $\mathrm{Fe}(103.43$ and $56.546 \mathrm{mg} / \mathrm{kg})$, less $-\mathrm{Cd}$ and $\mathrm{Cu}(0.21$ and 0,16 $\mathrm{mg} / \mathrm{kg}$ ). The comparison of heavy metals concentration in embryonic soils of the coal waste dump with the Hygiene Regulations has not detected its MPC (APC) (Table 1).

It has been experimentally found that the rhizome and roots of Sanguisorba officinalis L. accumulate more biophilic metals: Fe $(61.95 \mathrm{mg} / \mathrm{kg}), \mathrm{Mn}(33.46 \mathrm{mg} / \mathrm{kg}), \mathrm{Zn}(17.53$ $\mathrm{mg} / \mathrm{kg})$ and $\mathrm{Cu}(12.35 \mathrm{mg} / \mathrm{kg})$. The obtained results comply with the literature data [13]. The increased need of the plants in biophilic metals is obviously connected with its participation in the vital biochemical processes that determine the normal growth and development. Content of technogenic group elements in Sanguisorba officinalis L. raw material $(\mathrm{Pb}, \mathrm{Cd}, \mathrm{Cr}, \mathrm{Ni}, \mathrm{Co})$ is characterized by low values within $0.04-1.52 \mathrm{mg} / \mathrm{kg}$.

We have not found a direct relation between the heavy metals concentration in plants and the associated embryonic soils, what confirms the fact of selective absorption of the chemical elements by plants [10].

MPC-GN 2.1.7.2041-06. Maximum permissible concentration (MPC) of chemicals in soil: Hygienic standards (2006), APC* is roughly allowable concentration; MPC for $\mathrm{BAA}^{* *}$ (SanPin 2.3.2.1078-01. 2002).

Despite the features of selective absorption of heavy metals Sanguisorba officinalis L., their content in rhizomes and roots does not exceed the MPC and their actual content is several times lower than the norm (Table 1) [12].

The artificial radionuclides $\mathrm{Sr}-90$ and $\mathrm{Cs}-137$ content is regulated in medicinal plant raw materials.However, it was interesting to study the correlation artificial and natural radionuclides content by the underground organs of investigating medicinal plant. 
Table 1. Heavy metals content in embryonic soils and raw plant material of Sanguisorba officinalis L. in the circumstances of the rock waste disposal area of the Kedrovsky coal pit.

\begin{tabular}{|c|c|c|c|c|}
\hline \multirow{2}{*}{ Elements } & \multicolumn{4}{|c|}{ Content of elements, mg/kg } \\
\cline { 2 - 5 } & \multicolumn{2}{|c|}{ Embryonic soils } & \multicolumn{2}{c|}{ Raw material } \\
\cline { 2 - 5 } & Mobile form & $\begin{array}{c}\text { MPC, APC } \\
*\end{array}$ & Rhizome and roots & $\begin{array}{c}\text { MPC for } \\
\text { BAA** }\end{array}$ \\
\hline $\mathrm{Pb}$ & $1.92 \pm 0.087$ & 6.0 & $0.74 \pm 0.06$ & 6.0 \\
\hline $\mathrm{Cd}$ & $0.21 \pm 0.003$ & 1.0 & $0.04 \pm 0.008$ & 1.0 \\
\hline $\mathrm{Cu}$ & $0.16 \pm 0.003$ & 3.0 & $12.35 \pm 0.29$ & - \\
\hline $\mathrm{Zn}$ & $2.08 \pm 0.038$ & 23.0 & $17.53 \pm 0.61$ & - \\
\hline $\mathrm{Mn}$ & $103.43 \pm 1.26$ & $140-500$ & $33.46 \pm 2.40$ & - \\
\hline $\mathrm{Ni}$ & $2.63 \pm 0.14$ & 4.0 & $1.52 \pm 0.02$ & - \\
\hline $\mathrm{Co}$ & $0.83 \pm 0.03$ & 5.0 & $0.93 \pm 0.08$ & - \\
\hline $\mathrm{Fe}$ & $56.54 \pm 0.72$ & - & $61.95 \pm 3.78$ & - \\
\hline $\mathrm{Cr}$ & $2.04 \pm 0.04$ & 6.0 & $0.86 \pm 0.05$ & - \\
\hline
\end{tabular}

We have not found that the content of natural and artificial radionuclides in embryonic soils is higher than in raw materials (Table 2). At the same time the main share of radioactivity falls to natural radionuclides. First of all, it refers to the K-40. Its share to overall radioactivity is $78 \%$, for the artificial radionuclides in embryonic soils $-7 \%$ (Table 2, Fig. 1).

Table 2. Radionuclides content in embryonic soils and raw plant material of Sanguisorba officinalis L. in the circumstances of the rock waste disposal area of the Kedrovsky coal pit.

\begin{tabular}{|c|c|c|c|c|c|c|}
\hline \multirow[b]{3}{*}{ Rn } & \multicolumn{6}{|c|}{ Specificactivity. Bq/kg } \\
\hline & \multirow[b]{2}{*}{$\begin{array}{c}\text { Embr } \\
\text { yonic } \\
\text { soils }\end{array}$} & \multirow[b]{2}{*}{$\begin{array}{c}\text { Average } \\
\text { regional } \\
\text { level } \\
{[14]}\end{array}$} & \multirow[b]{2}{*}{$\begin{array}{l}\text { Background } \\
\text { rate of } \\
\text { natural } \\
\text { radionuclides } \\
\quad[15]\end{array}$} & \multirow[b]{2}{*}{$\begin{array}{l}\text { Rhizome and } \\
\text { roots of } \\
\text { Sanguisorba } \\
\text { officinalis L. }\end{array}$} & \multicolumn{2}{|c|}{ МРC[12] } \\
\hline & & & & & $\begin{array}{c}\text { for } \\
\text { BAAA }\end{array}$ & $\begin{array}{l}\text { Raw } \\
\text { materials } \\
\text { (grass. bark. } \\
\text { under. stem. } \\
\text { fruits) }\end{array}$ \\
\hline Sr-90 & $\begin{array}{c}1.26 \pm \\
0.11\end{array}$ & $20-25$ & - & $0.72 \pm 0.03$ & 200 & 400 \\
\hline $\begin{array}{l}\text { Cs- } \\
137\end{array}$ & $\begin{array}{c}3.22 \pm \\
0.10\end{array}$ & 20.1 & - & $1.65 \pm 0.20$ & 100 & 200 \\
\hline $\mathrm{K}-40$ & $\begin{array}{l}552.0 \\
\pm 9.81\end{array}$ & - & $40-1000$ & $23.67 \pm 0.44$ & - & - \\
\hline $\begin{array}{l}\text { Th- } \\
232\end{array}$ & $\begin{array}{l}31.98 \\
\pm 1.10\end{array}$ & - & 40 & $2.24 \pm 0.14$ & - & - \\
\hline $\begin{array}{l}\text { Ra- } \\
226\end{array}$ & $\begin{array}{l}21.83 \\
\pm 0.64\end{array}$ & - & 40 & $2.79 \pm 0.06$ & - & - \\
\hline
\end{tabular}




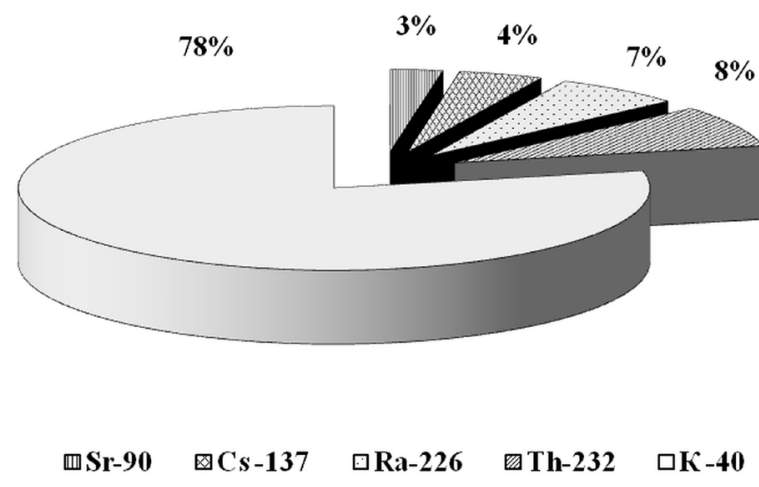

Fig.1. Comparative assessment of the content of artificial and natural radionuclides in embryonic soils.

The obtained results evidence absence of pollution of embryonic soil of the rock waste disposal areas with artificial radionuclides - the content of Sr-90 and Cs-137 is significantly lower than the average regional degree of accumulation for the soil in the Tomsk region bordering with the Kemerovo region [14]; and the content of natural radionuclides is within the background rate of radioactive elements in the Earth crust [15].

Analysis of radioactivity of Sanguisorba officinalis L. raw material revealed relatively high value of the weighted average relative activity of K-40. The share of K-40 in the overall radioactivity is equal to $76 \%$. This proves the necessity of $\mathrm{K}-40$ for normal growth of plants. The absolute values of relative activity of Th-232 and Ra-226 are lower than the absolute value of K-40, and their share in the overall radioactivity is equal to just $7 \%$ and $9 \%$ accordingly. It is a known fact that unlike radionuclides of potassium, Th-232 and Ra-226 are not vital elements for plants [16].

The share of the anthropogenic radionuclides Cs-137 and Sr-90 in Sanguisorba officinalis L. raw material are less than the share of the natural radionuclides and it is within $0,72-1,65 \mathrm{~Bq} / \mathrm{kg}$ which is 3 and $5 \%$ of the overall radioactivity accordingly (Table 2, Fig. 2).

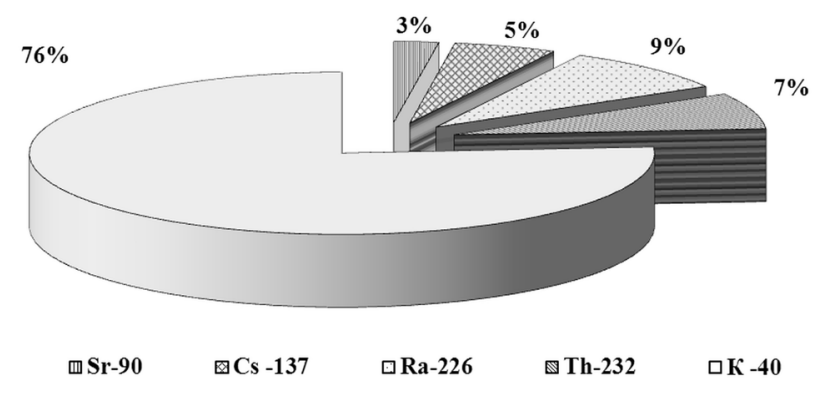

Fig.2. Comparative assessment of the content of artificial and natural radionuclides in rhizome and roots of Sanguisorba officinalis L.

Hygienic assessment of rhizome and roots of Sanguisorba officinalis L., grown at the Yuzhny rock waste disposal area of the Kedrovsky coal pit, has shown that the contain of artificial radionuclides - Sr-90 and Cs-137 - does not exceed the maximum allowable 
concentration as per SanPiN 2.3.2.1078-01 and is not dangerous for the health of consumers.

\section{Conclusion}

It has been experimentally proven that the medicinal plan product of Sanguisorba officinalis L. (rhizome and roots) grown at waste dump of the Kedrovsky open pit coal mine is ecologically safe as far as ecotoxicants like heavy metals are concerned.

\section{Acknowledgement}

The work was carried out according to the state task - № 0352-2016-0002.

\section{References}

1. I. N. Egorova, The possibility of using the reclaimed lands of the coal mine "Kedrovskii" for the harvesting of medicinal plant raw material (KemSU, Kemerovo, 2011)

2. Yu. A. Manakov, T. O. Strelnikova, A. N. Kupriyanov, The Formation of Plant Cover in Man-Made andscapes of the Kuznetsk Basin (SO RAN, Novosibirsk, 2011)

3. D. A. Muraveva, I. A. Samilina, G. P. Yakovlev, Pharmacognosy (Medicine, Moscow, 2002)

4. Z. Zhao, X. He, Q. Zhang, X. Wei, L. Huang, J.C. Fang, X. Wang, M. Zhao, Y. Bai, X. Zheng, Am. J. Chin. Med., 45, 89-96 (2017)

5. S. Zhang, X. Liu, Z.L. Zhang, L. He, Z. Wang, G.S. Wang, J. Molecules, 23, 133-147 (2012)

6. A. S. Hamicaeva, F. L. Kudzieva, F. I. Budaev, Food Thechnology, 4, 358 (2017)

7. Kh. A. Iskhakov, E.L. Schastlivtsev, Yu. A. Kondratenko, M.L. Lesina, Koksi Khimia Journal, 5, 41-45 (2010)

8. A. S. Fedotova, Mining informational and analytical bulletin, 1, 201-205 (2006)

9. I. V. Gravel, Regional problems of environmental assessment of MRH and herbal medicinal products on the example of the Altai Territory (MSU, Moscow, 2005)

10. A. Kabata-Pendias, A. B. Mukherjee, Trace Elements from Soil to Human (GDFN, Berlin, 2007)

11. N. Egorova, O. A. Neverova, L. S. Dyshlyuk, Modern appled science, 4, 270-275 (2015)

12. The Sanitary and Epidemiological Rules and Regulations "Hygienic Requirements for Safety and Nutrition Value of Food Products" (Standards, Moscow, 2002)

13. O. N. Egorova, I. N. Egorova, T. I. Grigorieva, Problems of nature protection organization of landscapes, 1, 71-75 (2013)

14. L. P. Rikhvanov, General and regional problems of radioecology (TPU, Tomsk, 1997).

15. A. M. Ivlev, A. M. Derbeneva, Degrading Soil and its Reclamation, Study Guide (DSU Publishing House, Vladivostok, 2002).

16. N. A. Titaeva, Geochemistry of Radionuclides of Radioactive Elements (U, Th, Ra) (MSU, Moscow, 2002). 